\title{
Genetic control of white clover seed yield potential
}

\author{
D.R. WOODFIELD ${ }^{1}$, I.J. BAIRD ${ }^{2}$ and P.T.P. CLIFFORD ${ }^{3}$ \\ ${ }^{1}$ AgResearch, Grasslands Research Centre, P B 11008, Palmerston North \\ ${ }^{2}$ AgResearch, Canterbury Agriculture and Science Centre, P.O. Box 60, Lincoln \\ ${ }^{3}$ Retired, 26 Browns Road, Christchurch \\ derek.woodfield@agresearch.co.nz
}

\begin{abstract}
Improving the seed yield potential of new white clover (Trifolium repens L.) cultivars is critical to their commercial viability and to overcoming the increasing pressures from land use change in Canterbury. The genetic control and response to selection was investigated for two seed yield characteristics, inflorescence density $\left(\right.$ no. $\left./ \mathrm{m}^{2}\right)$ and seed yield per inflorescence $(\mathrm{g} /$ inflorescence). Inflorescence density and seed yield per inflorescence were both responsive to selection and acted independent of one another to increase seed yield. Selection for high inflorescence density resulted in 34\% higher seed yield than the low inflorescence density selection. This change in seed yield was associated with a 33\% higher inflorescence density, while seed yield per inflorescence was unchanged. Similarly, selection for seed yield per inflorescence resulted in a $17 \%$ difference in seed yield between the high (HYI) and low (LYI) seed yield per inflorescence selections. This change in seed yield was associated with a $24 \%$ higher yield per inflorescence for the HYI selection, while inflorescence density remained unchanged. These results confirm that both mechanisms are under independent genetic control and can be utilized to increase seed yield of new white clover cultivars.
\end{abstract}

Keywords: genetics, inflorescence density, seed production, Trifolium repens, white clover

\section{Introduction}

Improving the seed production potential of white clover cultivars is essential to the commercial viability of new cultivars and to the viability of white clover seed production in New Zealand. Land-use changes over the past decade in Canterbury, the single largest white clover seed production area internationally, have halved the suitable land available for seed production of proprietary white clover cultivars (Pyke et al. 2004). Large areas of land that were traditionally used for white clover seed production areas have been converted either directly to dairy farming or to growing supplementary feed for dairy cows. In addition, the cultivar change requirements, that are necessary to ensure the purity of new proprietary cultivars, increase the costs and risk for seed producers (Clifford et al. 1996). The simpler certification requirements for alternative cropping options such as wheat, barley and perennial ryegrass make these lower risk crops with more predictable financial returns.

The ability to produce acceptable seed yields is essential for the commercial viability of any cultivar. Inferior seed production potential has resulted in the commercial failure of many white clover cultivars that had outstanding agronomic performance, including Tillman (USA), Siral (Australia) and a host of European cultivars (Davies 1984; Caradus \& Woodfield 1997). Similarly, the favourable climate for white clover seed production in Canterbury and the technical expertise of our seed producers, in comparison to many overseas regions, has led to significant pressure on white clover area from overseas cultivars multiplied here for export particularly to Europe. Since this practice began in 1985 (Mather et al. 1996) the number of overseas cultivars has increased to 36 in the 2003/2004 season (AgriQuality 2003).

New Zealand-bred white clover cultivars currently dominate all sectors of the NZ pastoral industry due to their superior adaptation and agronomic performance (Woodfield et al. 2001, 2003). Screening and selection for improved white clover seed production ability has been an important part in the development of New Zealand-bred white clover cultivars released in the past decade (Clifford et al. 1996; Widdup et al. 2004). Reliable seed availability is important to ensure that the future demands for white clover by New Zealand agriculture can be met. Clifford \& Baird (1993) identified two traits that contribute to improved seed yield in white clover. The first involves increasing the number of inflorescences per unit area, hereafter referred to as inflorescence density. The second mechanism involves producing and provisioning higher seed yield per inflorescence through to harvest, hereafter referred to as yield per inflorescence. Yield per inflorescence is a combination of the number of seeds per inflorescence (seeds/floret and florets/inflorescence) and 1000 -seed weight. We have chosen to use yield per inflorescence as a selection tool in our breeding programme, rather than its components, since the extra resource required to measure the various components on large breeding populations is impractical. This paper investigates the genetic control and relationship between inflorescence density, yield per inflorescence and seed yield per plant. 
Table 1 Climatic data for Lincoln, Canterbury between October and February of 1998/1999 and 1999/2000 seed production seasons.

\begin{tabular}{lcccc}
\hline Season & $\begin{array}{c}\text { Rainfall } \\
(\mathrm{mm})\end{array}$ & $\begin{array}{c}\text { Mean air } \\
\text { temperature } \\
\left({ }^{\circ} \mathrm{C}\right)\end{array}$ & $\begin{array}{c}\text { Solar radiation } \\
\left(\mathrm{MJ} / \mathrm{m}^{2}\right)\end{array}$ & $\begin{array}{c}10 \mathrm{~cm} \text { soil } \\
\text { temperature } \\
\left({ }^{\circ} \mathrm{C}\right)\end{array}$ \\
\hline $1998 / 1999$ & 176.1 & 14.7 & 643 & 17.7 \\
$1999 / 2000$ & 255.4 & 13.9 & 616 & 15.9 \\
\hline
\end{tabular}

Figure 1 Seed yield (g/plt) of $F_{1}$ lines in 1998/1999 and 1999/2000. (High inflorescence density, HID; low inflorescence density, LID; high yield per inflorescence, HYI; and low yield per inflorescence, LYI).

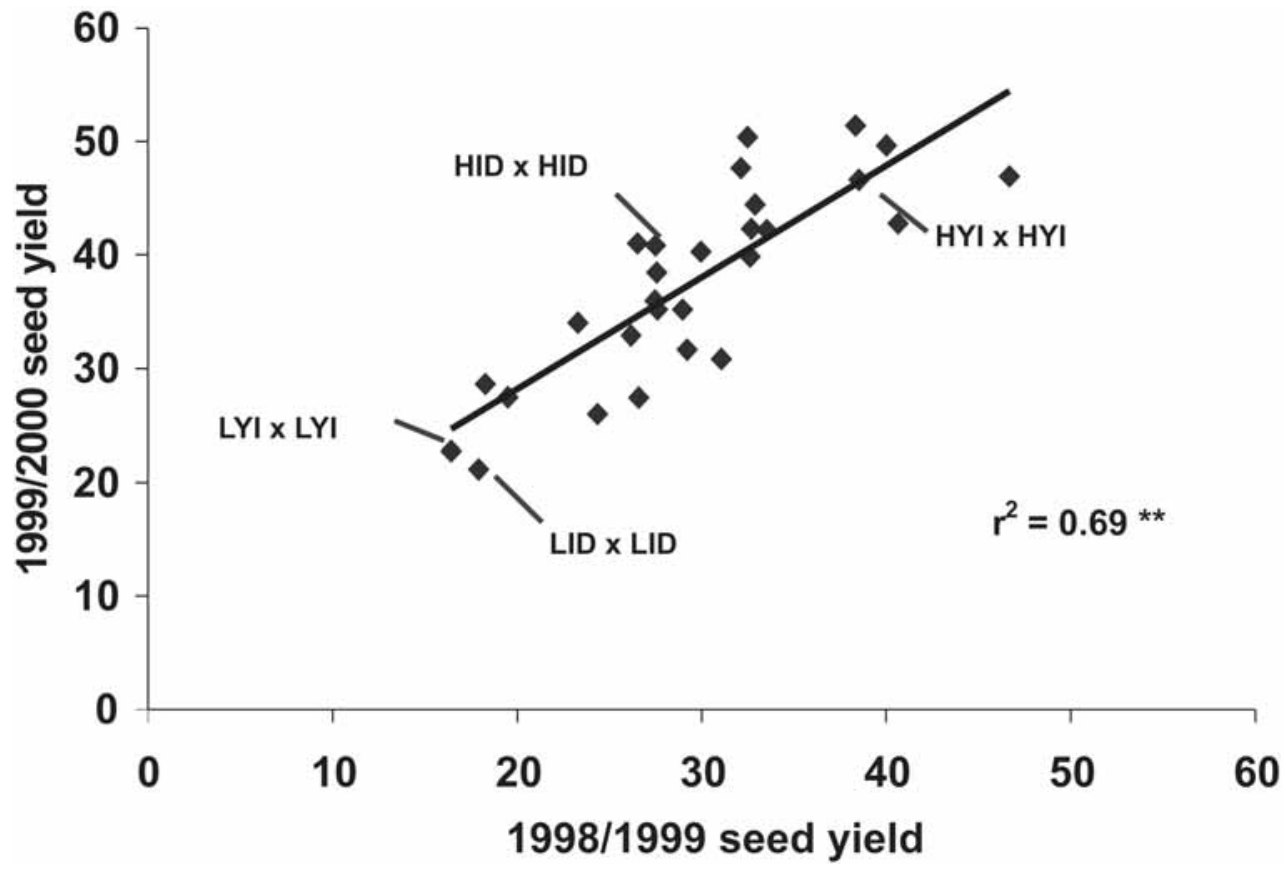

Table 2 Mean leaf size, seed yield and seed yield components of 4 selection groups in 1998/1999 and 1999/ 2000. (High inflorescence density, HID; low inflorescence density, LID; high yield per inflorescence, $\mathrm{HYl}$; and low yield per inflorescence, LYI).

\begin{tabular}{lcccc}
\hline Selection & $\begin{array}{c}\text { Seed yield } \\
\text { (g/plt) }\end{array}$ & $\begin{array}{c}\text { Inflorescence } \\
\text { density } \\
\text { (no./plt) }\end{array}$ & $\begin{array}{c}\text { Yield per } \\
\text { inflorescence } \\
\text { (g/inflorescence) }\end{array}$ & $\begin{array}{c}\text { Leaf width } \\
(1-5)\end{array}$ \\
\hline HID & 38.3 & 203 & 0.196 & 3.0 \\
LID & 28.6 & 153 & 0.196 & 3.3 \\
HYI & 36.4 & 186 & 0.203 & 3.2 \\
LYI & 31.2 & 193 & 0.163 & 3.4 \\
LSD $_{0.05}$ & 2.1 & 9 & 0.011 & 0.2 \\
\hline
\end{tabular}

\section{Materials and methods}

White clover genotypes with high seed yield were isolated from a range of pre-release cultivars screened at Lincoln between 1990 and 1995. These selected genotypes were polycrossed to provide a gene pool for genetic studies of seed yield characteristics. In 1996, an $\mathrm{F}_{2}$ population was developed by intermating $\mathrm{F}_{1}$ genotypes that had been selected for either high inflorescence density or high seed yield per inflorescence. This $\mathrm{F}_{2}$ population was screened at Lincoln in summer 1996/1997 and 200 plants were assessed for a range of morphological and reproductive traits including leaf size (visual score $1=$ very small to $5=$ very large $)$, seed yield $\left(\mathrm{g}\right.$. plant $\left.\mathrm{t}^{-1}\right)$, inflorescence density (no. plant ${ }^{-1}$ ) and yield per 
inflorescence. Based on these data, two plants were identified from each of four categories: high inflorescence density (HID), low inflorescence density (LID), high yield per inflorescence (HYI), and low yield per inflorescence (LYI). The selected HID and LID plants differed four-fold in both seed yield and inflorescence density, but did not differ in yield per inflorescence. Similarly, the selected HYI plants had four-fold higher seed yield and yield per inflorescence than the selected LYI plants but did not differ for inflorescence density. An eight-parent diallel was developed in 1997 by hand with emasculation before pollination to prevent any possible selfing. Reciprocal crosses were bulked after harvest to provide $28 \mathrm{~F}_{1}$ lines since no maternal effects have been reported for seed yield characters in white clover.

Twenty plants from each of the $28 \mathrm{~F}_{1}$ lines were sown in May 1998 and again in May 1999, and grown in root trainers outside to allow for cold induction. These plants were transplanted into the field at $0.8-\mathrm{m}$ spacings in midSeptember at Lincoln and grown as spaced plants in summer 1998/1999 and 1999/2000. The experimental design was a randomised complete block design with 20 replicates of a single plant from each $\mathrm{F}_{1}$ line. In the second year, one line (LID62 x LYI328) had only eight plants due to low seed numbers in the original diallel cross. Three further lines (HID292 x LID303, HID292 x LID62 and HID292 x LYI328) had reduced final plant numbers in both years due to the presence of $25 \%$ sterile plants. The spaced plants were assessed throughout both summers for leaf size using a visual 5 point score ( $1=$ very small to $5=$ very large), and were harvested individually in February of both years. The number of inflorescences per plant was determined prior to threshing to obtain seed yield (g) per plant. Yield per inflorescence was calculated as $\mathrm{g}$ of seed per inflorescence, and as such is a combination of two potential seed yield components, number of seeds per inflorescence and 1000 -seed weight. Analysis of variance was done for seed yield and seed yield components of the $28 \mathrm{~F}_{1}$ lines across both years using SAS Proc GLM. Analysis of variance was also done based on the four selection groups (HID, LID, HYI and LYI). To do this each $\mathrm{F}_{1}$ line contributed to these groups based on the respective $F_{1}$ parents, for example HID292 x LYI328 contributed to both HID and LYI group means, while LID62 x LID303 contributed twice to the LID mean. Finally data were analysed across the 10 possible crosses within (HID x HID, LID x LID, HYI x HYI, and LYI x LYI) and between (HID x LID, HID x HYI, HID x LYI, LID x HYI, LID x LYI, HYI x LYI) selection groups.

\section{Results}

The two seed production seasons (October to February) differed climatically (Table 1) with the 1998/1999 season being drier, warmer and having higher sunlight hours than the 1999/2000 season. This resulted in significantly lower mean seed yield in the first season $(29.6 \mathrm{~g} / \mathrm{plt})$ than the second season $(37.7 \mathrm{~g} / \mathrm{plt})$. There was no change in the mean number of inflorescences per plant with 181 in $1998 / 1999$ and 186 in 1999/2000. However, there was a $28 \%$ increase in yield per inflorescence in the second year, while leaf size was also significantly (2.9 vs 3.5) larger.

The seed yield of the $28 \mathrm{~F}_{1}$ lines was consistent between years with a highly significant correlation $\left(\mathrm{r}^{2}=0.69^{* *}\right.$; Figure 1). The seed yield per plant showed significant improvement through selection for both inflorescence density and yield per inflorescence (Figure 1). Seed yield per plant of the HID x HID $\mathrm{F}_{1}$ line was $54 \%$ and $92 \%$ higher than for its LID $x$ LID counterpart in the two years, respectively. This improvement was smaller than the $135 \%$ and $105 \%$ difference in seed yield per plant observed for the HYI x HYI F line compared to its LYI $\mathrm{x}$ LYI counterpart in year 1 and 2, respectively (Figure 1). Two $F_{1}$ lines had slightly higher mean seed yields in both years than the HYI x HYI line and both were crosses between HYI and HID parents (Figure 1).

The correlation between inflorescence density of the $\mathrm{F}_{1}$ lines in year 1 and 2 was even stronger $\left(\mathrm{r}^{2}=0.80^{* *}\right.$; Figure 2) than for seed yield (Figure 1). The inflorescence density of the HID x HID $\mathrm{F}_{1}$ line was more than double (133\% and 144\% higher in year 1 and 2 respectively) that of the LID x LID selection. Notably, there was no significant difference in inflorescence density between the HYI x HYI and LYI x LYI selections in either year (Figure 2).

The yield per inflorescence of the $28 \mathrm{~F}_{1}$ lines correlated $\left(\mathrm{r}^{2}=0.60^{* *}\right)$ strongly between years (Figure 3$)$. The yield per inflorescence of the HYI x HYI $F_{1}$ selection was at least double (113\% and $100 \%$ higher in year 1 and 2 respectively) that of the LYI x LYI selection. There was also a significant difference in yield per inflorescence between the HID x HID and LID x LID selections (Figure 3 ). This $52 \%$ and $27 \%$ difference in favour of the LID $x$ LID selection in year 1 and 2, respectively, was not expected since the inflorescence density parents had been selected for similar yield per inflorescence.

The mean seed yield and seed yield components for the four selection groups (HID, LID, HYI and LYI) are summarised in Table 2. Seed yield was $34 \%$ higher overall for lines that had a HID parent than for those that had a LID parent, and this increase was predominantly associated with a $33 \%$ increase in inflorescence density (Table 2). There was no change in yield per inflorescence between HID and LID groups, but there was a small and significant increase in leaf size. Lines that had a HYI parent had on average $17 \%$ greater seed yield per plant 
Figure 2 Inflorescence density (no./plt) of $28 \mathrm{~F}_{1}$ lines in 1998/1999 and 1999/2000. (High inflorescence density, HID; low inflorescence density, LID; high yield per inflorescence, HYI; and low yield per inflorescence, LYI).

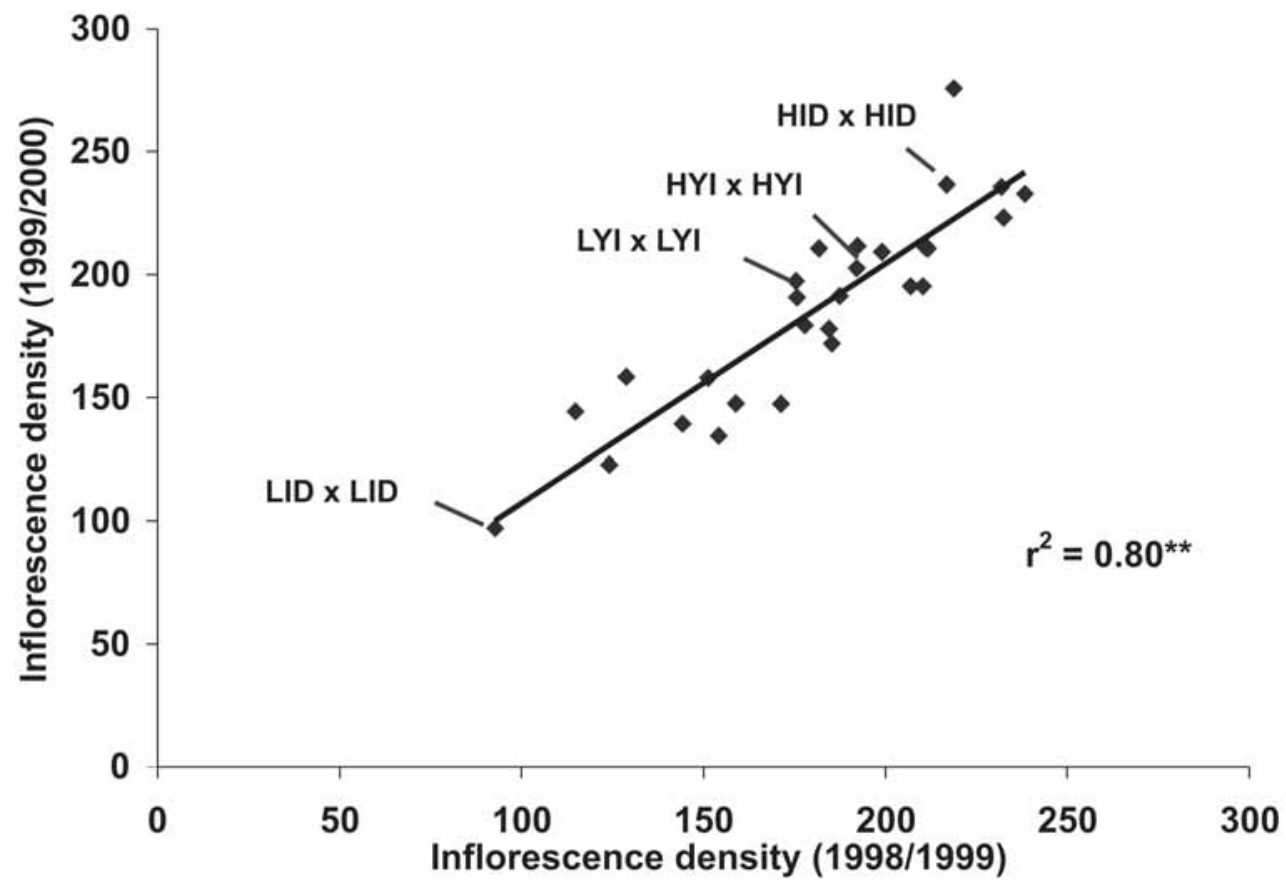

Figure 3 Seed yield per inflorescence (g/inflorescence) of $28 F_{1}$ lines in 1998/1999 and 1999/2000. (High inflorescence density, HID; low inflorescence density, LID; high yield per inflorescence, HYI; and low yield per inflorescence, LYI).

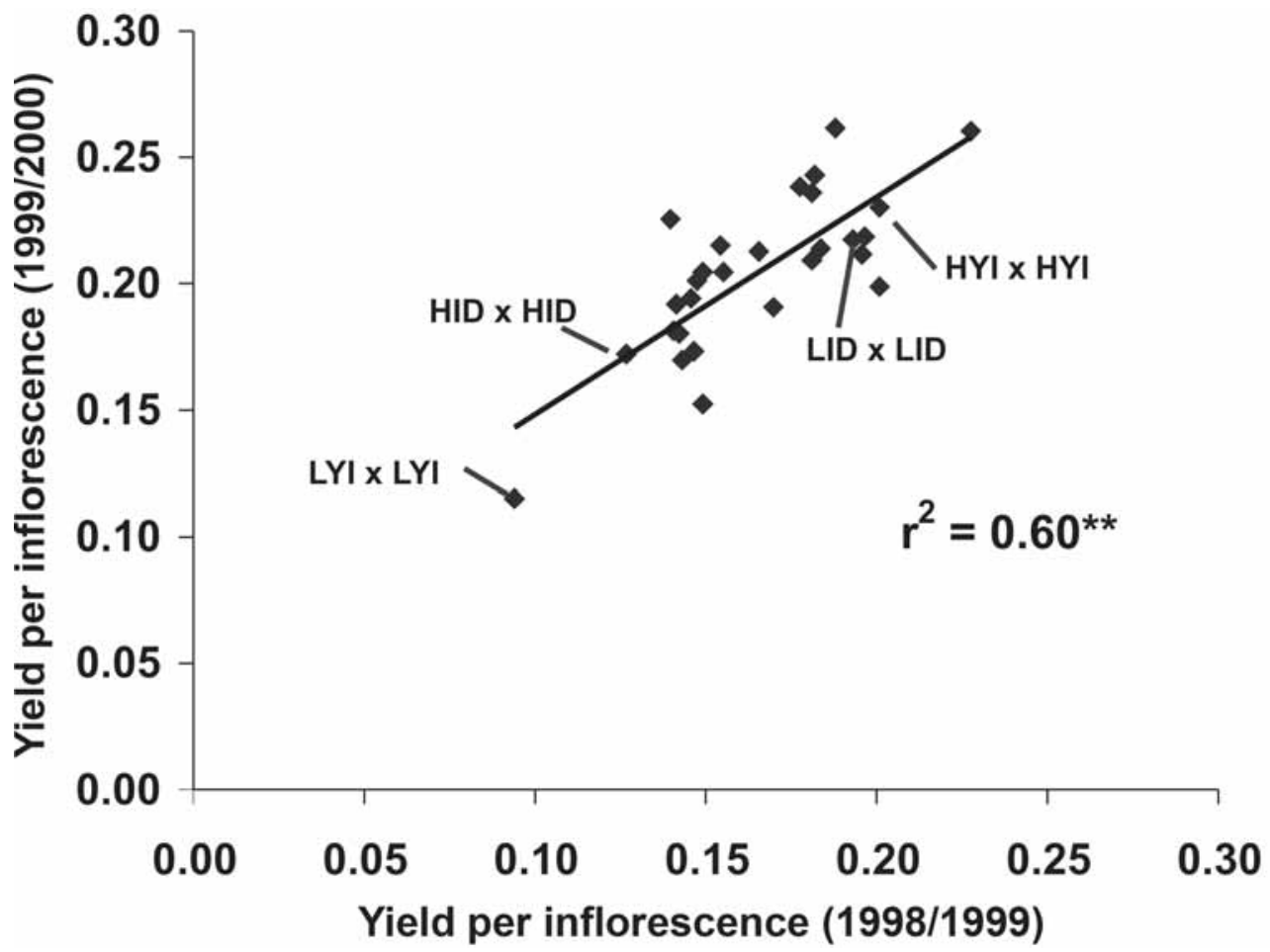


Table 3 Seed yield, inflorescence density, yield per inflorescence and leaf width of crosses within and between selection groups in 1998/1999 and 1999/2000. (High inflorescence density, HID; low inflorescence density, LID; high yield per inflorescence, HYI; and low yield per inflorescence, LYI).

\begin{tabular}{lccccc}
\hline Cross & Lines $^{1}$ & $\begin{array}{c}\text { Seed } \\
\text { yield } \\
\text { (g/plt) }\end{array}$ & $\begin{array}{c}\text { Inflorescence } \\
\text { density } \\
\text { (no/plt) }\end{array}$ & $\begin{array}{c}\text { Yield per } \\
\text { inflorescence } \\
\text { (g/inflorescence) }\end{array}$ & $\begin{array}{c}\text { Leaf } \\
\text { width } \\
(1-5)\end{array}$ \\
\hline HID x HID & 1 & 34.16 & 227 & 0.151 & 2.40 \\
HID x LID & 4 & 34.82 & 172 & 0.213 & 3.05 \\
LID x LID & 1 & 19.46 & 94 & 0.219 & 3.20 \\
HID x HYI & 4 & 43.12 & 205 & 0.218 & 2.96 \\
HID x LYI & 4 & 39.00 & 221 & 0.179 & 3.27 \\
LID x HYI & 4 & 29.13 & 149 & 0.204 & 3.24 \\
LID x LYI & 4 & 26.57 & 166 & 0.161 & 3.68 \\
HYI x HYI & 1 & 42.58 & 197 & 0.223 & 3.45 \\
HYI x LYI & 4 & 33.82 & 197 & 0.176 & 3.18 \\
LYI x LYI & 1 & 19.57 & 186 & 0.106 & 3.55 \\
LSD $_{0.05}$ & & 3.22 & 14 & 0.016 & 0.28 \\
\hline
\end{tabular}

${ }^{1}$ Number of lines contributing to crossing group mean.

than those that had a LYI parent (Table 2). This change was associated with an increase of $24 \%$ in yield per inflorescence between HYI and LYI groups, while there was no significant change in inflorescence density or leaf size.

The mean seed yield and seed yield components of the 10 crosses within and between the selection groups also highlights some important points. There is a strong increase in seed yield for the HID x HID and HID x LID crosses compared to the LID x LID cross (Table 3 ). The HID x HID cross had higher inflorescence density than the HID x LID and LID x LID crosses, however, a decrease in yield per inflorescence in the HID x HID resulted in its mean seed yield being equal to that of the HID x LID cross. There was also a consistent decrease in leaf size with increased inflorescence density among these three crosses (Table 3).

The crosses within yield per inflorescence groups (HYI x HFI, HYI x LYI and LYI x LYI) showed a strong increase in seed yield associated with an equivalent increase in yield per inflorescence. Importantly, there was no correlated change in inflorescence density or leaf size (Table 3). In the inter-group crosses between ID and YI, the trend was for crosses involving HID to have significantly higher seed yield than those involving LID or LYI. The best seed yield among crosses was for HID $\mathrm{x}$ HYI, although this was equaled by the HYI x HYI cross (Table 3 ).

\section{Discussion}

Our results indicate that the seed yield potential of white clover cultivars can be improved through selection for increased inflorescence density and increased yield per inflorescence. Furthermore, the practical benefits of incorporating selection for these seed yield characteristics into the breeding programme has been shown to have improved the seed yield potential of six recent NZ cultivars (Widdup et al. 2004). Improvements in seed yield were achieved irrespective of the leaf size or enduse of these cultivars, with improved seed yield observed in cultivars ranging from small-leaved cultivars, developed for intensive sheep-grazed systems, through to large-leaved cultivars for dairy systems.

In the current gene pool, both traits appear to be under separate genetic control and can be manipulated individually, or in combination, to increase white clover seed yield. Efforts to locate quantitative trait loci (QTL) for these two seed yield traits have identified major QTL for both yield per inflorescence and inflorescence density that account for approximately $50 \%$ of the variation in each (Barrett et al. 2004). Barrett et al. (2004) also confirmed that different QTL were associated with each trait.

Increased inflorescence density has been identified previously as a major factor in obtaining high white clover seed yield (Clifford 1987; Van Bockstaele \& Rijckaert 1988; Clifford \& Baird 1993; Williams et al. 1998). Inflorescence density was very responsive to selection and had a narrow sense heritability of 0.9 . The change in seed yield associated with selection for increased inflorescence density was about double that associated with selection for yield per inflorescence. Widdup et al. (2004) also found that the improvement in seed yield across generations in four out of six cultivars was predominantly associated with increased inflorescence density.

White clover inflorescences form in the leaf axils along stolons (Thomas 1961; Clifford 1985) and cultivars with 
higher stolon density and smaller leaf size usually have higher inflorescence densities (Clifford 1987; Williams et al. 1998). Comparisons of seed yield potential amongst cultivars have frequently identified that larger-leaved cultivars have lower stolon density, fewer leaves per $\mathrm{m}^{2}$, lower inflorescence densities and lower seed yield than smaller-leaved cultivars (Clifford 1985, 1986, 1987). A potential concern is that selection for increased inflorescence density could result in a correlated decrease in leaf size and stolon density and therefore reduce the persistence of the final cultivar. In the current study, the higher seed yield of HID crosses was associated with a reduction in leaf size, but this change in seed yield was far greater than would be anticipated from this shift in leaf size. The impact on agronomic performance of changes in leaf size and other morphological traits during the process of selection for seed yield needs to confirmed in grazing experiments.

A major objective of the NZ white clover breeding programme has been to develop cultivars, such as Grasslands Sustain and Grasslands Kopu II, that have higher stolon densities per unit leaf area (Caradus et al. 1997; Woodfield et al. 2001, 2003). Selection for increased stolon density plays a dual role since higher stolon densities can improve agronomic potential and can also improve seed yield potential through higher inflorescence density. Widdup et al. (2004) found that the seed yields of large-leaved cultivars Kopu II and Sustain were as good as those of Prestige, the smallleaved cultivar with the highest inflorescence density in their study.

It is clear that increased inflorescence density is not the only factor required for high seed yield. Williams et al. (1998) found that while the inflorescence density deceased as leaf size increased among 15 white clover cultivars, the seed yield potential was quite similar across leaf size categories. They found that the higher yield per inflorescence of large-leaved cultivars was associated with more seeds per floret. In the present study, improving yield per inflorescence had a marked effect on seed yield, and although the magnitude of this change was smaller than that associated with inflorescence density, it occurred without any correlated change of leaf size. Improved yield per inflorescence is therefore an important mechanism in breeding pools where a change in leaf size may adversely affect agronomic performance. The lower narrow sense heritability of 0.4 for yield per inflorescence reflects the composite nature of this trait, but also indicates that it can be used in selection for enhanced seed yield. The potential contribution from improved yield per inflorescence is further emphasized by the HYI $x$ HYI $F_{1}$ and two HID x HYI $F_{1}$ s having the highest seed yields in this gene pool.

Clifford and Baird (1993) found that seeds per floret and seeds per inflorescence had the strongest association with yield per inflorescence, while high 1000 -seed weights were generally associated with low seed set and hence low yield per inflorescence. Barrett et al. (2004) did not find any association between 1000 -seed weight and QTL identified for seed yield per inflorescence. This probably indicates that heritable changes in yield per inflorescence are due to more seeds per floret or more florets per inflorescence rather than increased 1000 -seed weight.

Adverse environmental conditions have a direct affect on yield per inflorescence. The drier and warmer 1998/ 1999 season did not affect inflorescence density but did have a significant impact on yield per inflorescence. Clifford (1986) also reported that moisture stress reduced yield per inflorescence but did not affect crop flowering. However, Clifford (1986) concluded that irrespective of moisture, maximizing the number of ovules taken through to harvest almost totally accounted for higher seed yields. Hence, both inflorescence density and yield per inflorescence are important contributors to final seed yield.

The strong genetic control of, and considerable genetic variation for, seed yield and the two yield components reported here indicate that there is considerable room to improve the seed yield potential of white clover. Falcinelli (1999) reported that the maximum yield potential for white clover was about $1800 \mathrm{~kg} / \mathrm{ha}$. However this estimate was based on 600 inflorescences per $\mathrm{m}^{2}$ and a 1000 -seed weight of $0.5 \mathrm{~g}$. These estimates are low by New Zealand standards where inflorescence densities regularly exceed 800 per $\mathrm{m}^{2}$ and densities over 2000 per $\mathrm{m}^{2}$ have been measured (Clifford 1987), and 1000-seed weights regularly exceed $0.7 \mathrm{~g}$. Based on conservative estimates of 800 inflorescences per $\mathrm{m}^{2}$ and yields per inflorescence of $0.25 \mathrm{~g}$, the seed yield potential of white clover is in excess of $2000 \mathrm{~kg} / \mathrm{ha}$. The best commercial cultivars are currently averaging around $1000 \mathrm{~kg} / \mathrm{ha}$ in commercial crops. Seed yields per inflorescence of $0.25 \mathrm{~g}$ are achievable, with Widdup et al. (2004) reporting that Kopu II achieved this level of yield per inflorescence. Harnessing genetic variation for inflorescence density and yield per inflorescence should contribute to the development of white clover cultivars with higher potential seed yields.

The ability to successfully commercialise new white clover cultivars in New Zealand in the future will be as dependent on their seed yield potential as on their agronomic performance. New Zealand-bred cultivars are screened routinely for seed production potential and should be better suited to meeting the challenges facing white clover seed production in New Zealand. Widdup et al. (2004) have clearly demonstrated that the strong genetic control of inflorescence density and yield per 
inflorescence identified in this study can be translated into increased seed yield of new cultivars.

\section{REFERENCES}

AgriQuality New Zealand 2003. Seed certification statistics 2003-2004. 57 pp.

Barrett, B.; Baird, I.J.; Woodfield, D.R. 2004. Genetic tools for increased white clover seed production. Proceedings of the New Zealand Grassland Association 66: 119-126.

Caradus, J.R.; Woodfield, D.R. 1997. World checklist of white clover varieties II. New Zealand Journal of Agricultural Research 40: 115-206.

Caradus, J.R., P.T.P. Clifford, D.F. Chapman, G.R. Cousins, W.M. Williams, and J.E. Miller. 1997. Breeding and description of Grasslands Sustain. New Zealand Journal of Agricultural Research 40:1-7.

Clifford, P.T.P. 1985. Effect of leaf area on white clover seed production. Grassland Research and Practice Series 2: 25-31.

Clifford, P.T.P. 1986. Interaction between leaf and seed production in white clover (Trifolium repens). Journal of Applied Seed Production 4: 37-43.

Clifford, P.T.P. 1987. Producing high seed yields from high forage producing white clover cultivars. Journal of Applied Seed Production 5: 1-9.

Clifford, P.T.P; Baird, I.J. 1993. Seed yield potential of white clover: characteristics, components and compromise. Proceedings of the XVII International Grassland Congress: 1678-1679.

Clifford, P.T.P.; Sparks, G.A.; Woodfield, D.R. 1996. The intensifying requirements for cultivar change. Agronomy Society of New Zealand Special Publication 11. White clover: New Zealand's competitive edge. Grassland Research and Practice Series 6: 19-24.

Davies, W.E. 1984. A decade of progress in clover breeding. Span 27(3):129-131.

Falcinelli, M. 1999. Temperate forage seed production: conventional and potential breeding strategies. Journal of New Seeds 1: 37-66.

Mather, R.D.J.; Melhuish, D.T.; Herlihy, M. 1996. Trends in the global marketing of white clover cultivars. White clover: New Zealand's competitive edge. Agronomy Society of New Zealand Special Publication 11/Grassland Research and Practice Series 6: 7-14.

Pyke, N.; Rolston, M.P.; Woodfield, D.R. 2004. National and export trends in herbage seed production. Proceedings of the New Zealand Grassland Association 66: 95-102.

Thomas, R.G. 1961. The influence of environment on seed production capacity in white clover (Trifolium repens L.). I. Controlled environment studies. Australian Journal of Agricultural Research 12: 227 238.

Van Bockstaele, E.J.; Rijckaert, G. 1988. Potential and actual seed yield of white clover varieties. Plant Varieties and Seeds 1: 159-169.

Widdup, K.H.; Woodfield, D.R.; Baird, I.J.; Woodfield, D.R. 2004. Response to selection for seed yield in six white clover cultivars. Proceedings of the New Zealand Grassland Association 66: 103-110.

Williams, T.A.; Abberton, M.T.; Thornley, W.J.; Evans, D.R.; Rhodes, I. 1998. Evaluation of seed production potential in white clover (Trifolium repens $\mathrm{L}$.) varietal improvement programmes. Grass and Forage Science 53: 197-207.

Woodfield, D.R.; Clifford, P.T.P.; Cousins, G.R.; Ford, J.L.; Baird, I.; Miller, J.E.; Woodward S.L.; Caradus, J.R. 2001. Grasslands Kopu II and Crusader: New generation white clovers. Proceedings of the New Zealand Grassland Association 63: 103-108.

Woodfield, D.R.; Clifford, P.T.P; Baird, I.; Cousins, G.R.; Miller, J.E.; Widdup, K.H.; Caradus, J.R. 2003. Grasslands Tribute: a multi-purpose white clover for Australasia. Proceedings of the New Zealand Grassland Association 65: 157-162. 
